\title{
Efek Antiinflamasi Ekstrak Etanol Rimpang Kunyit (Curcuma domestica Val.) pada Tikus Putih yang Diinduksi Karagenan
}

\author{
Antiinflammatory Effects of Ethanol Extract of Curcuma domestica Val. on \\ Carrageenan-induced White Mice \\ Rulia Meilina*1, Rasmadin Mukhtar ${ }^{2}$ \\ ${ }^{1}$ Program Studi Farmasi, Fakultas Ilmu Kesehatan Universitas Ubudiyah Indonesia, Jalan Alue Naga, Banda Aceh, Indonesia \\ ${ }^{2}$ Universitas Sumatera Utara, Medan, Indonesia \\ *Korespondensi Penulis: rulia.meilina@uui.ac.id
}

\begin{abstract}
Abstrak
Efek antiinflamasi ekstrak etanol rimpang kunyit dilakukan pada tikus putih yang diinduksi larutan karagenan (lambda carrageenan) 1\%, penelitian dilakukan dengan membagi hewan menjadi 5 kelompok. Kelompok A diberi CMC 0,5\%, kelompok B diberikan Indometasin dengan dosis $100 \mathrm{mg} / \mathrm{kgBB}$, kelompok C diberi ekstrak etanol rimpang kunyit dengan dosis $400 \mathrm{mg} / \mathrm{kgBB}$, kelompok D diberi ekstrak etanol rimpang kunyit dengan dosis $500 \mathrm{mg} /$ $\mathrm{kgBB}$, kelompok E diberi ekstrak etanol rimpang kunyit dengan dosis $600 \mathrm{mg} / \mathrm{kgBB}$. Hasil skrining fitokimia serbuk rimpang kunyit menunjukkan bahwa senyawa kimia yang terkandung adalah alkaloid, flavonoid, dan minyak atsiri. Hasil uji antiinflamasi menunjukkan bahwa ada perbedaan nyata antara kelompok tikus yang diberi suspensi CMC (kontrol), suspensi ekstrak etanol rimpang kunyit dengan dosis $400 \mathrm{mg} / \mathrm{kg} \mathrm{BB}, 500 \mathrm{mg} / \mathrm{kg} \mathrm{BB}, 600$ $\mathrm{mg} / \mathrm{kg}$ BB (uji bahan) dan suspensi indometasin dengan dosis $100 \mathrm{mg} / \mathrm{kg} \mathrm{BB}$ (perbandingan positif). Suspensi ekstrak etanol rimpang kunyit dengan dosis $600 \mathrm{mg} / \mathrm{kg} \mathrm{BB}$ menunjukkan bahwa kemampuan anti-inflamasi lebih baik daripada dosis $400 \mathrm{mg} / \mathrm{kg} \mathrm{BB}$ dan $500 \mathrm{mg} / \mathrm{kg} \mathrm{BB}$, dan suspensi ekstrak etanol rimpang kunyit dosis $600 \mathrm{mg} / \mathrm{kg} \mathrm{BB}$ menunjukkan efek antiinflamasi yang tidak benar-benar berbeda dengan suspensi indometasin dengan dosis $100 \mathrm{mg} / \mathrm{kg} \mathrm{BB}$, hal ini ditunjukkan oleh analisis statistik ANOVA di antara perbandingan tersebut terhadap suspensi indometasin sebagai perbandingan positif.
\end{abstract}

Kata kunci: antiinflamasi, indometasin, etanol rimpang kunyit

\begin{abstract}
Anti-inflammatory effect of ethanol rhizome of turmeric was conducted toward white mouse which is induced the carrageenan solution (lambda carrageenan) $1 \%$, research was conducted by dividing the animals into 5 groups. Group A was given CMC 0,5\%, group B was given Indometacin with dose $100 \mathrm{mg} / \mathrm{kgBB}$, group $C$ was given ethanol rhizome extract of turmeric with dose $400 \mathrm{mg} / \mathrm{kgBB}$, group D was given ethanol rhizome extract of turmeric with dose $500 \mathrm{mg} / \mathrm{kgBB}$, group $E$ was given ethanol rhizome extract of turmeric with dose 600 $m g / k g B B$. Result of phytochemical screening toward powder and ethanol extrat of rhizome of turmeric shows that chemical compounds which are involved are alkaloids, flavonoids, and aetheric oil. Result of anti-inflammatory test shows that there is the real difference among groups of mouse which were given CMC suspension (control), suspension of ethanol extracts
\end{abstract}


of turmeric's rhizome with dose $400 \mathrm{mg} / \mathrm{kg} \mathrm{BB}, 500 \mathrm{mg} / \mathrm{kg} \mathrm{BB}, 600 \mathrm{mg} / \mathrm{kg} \mathrm{BB}$ (material test) and suspension of indomethacin with dose $100 \mathrm{mg} / \mathrm{kg} \mathrm{BB}$ (positive comparison). Suspension of ethanol extract of turmeric's rhizome with dose $600 \mathrm{mg} / \mathrm{kg} B B$ shows that antiinflammatory capability is better than dose $400 \mathrm{mg} / \mathrm{kg} \mathrm{BB}$ and $500 \mathrm{mg} / \mathrm{kg} \mathrm{BB}$, and suspension of ethanol extract of turmeric's rhizome dose $600 \mathrm{mg} / \mathrm{kg} \mathrm{BB}$ shows the anti-inflammatory effect which is not really different with suspension of indomethacin with dose $100 \mathrm{mg} / \mathrm{kg} \mathrm{BB}$, it is showed by ANOVA statistic analysis among those comparisons toward indomethacin suspension as positive comparison.

Keywords: Anti-inflammatory, indomethacin, ethanol rhizome of turmeric

\section{PENDAHULUAN}

Inflamasi merupakan suatu respon protektif normal terhadap luka jaringan yang disebabkan oleh trauma fisik, zat kimia yang merusak atau zat-zat mikrogenik. Inflamasi adalah usaha tubuh untuk menginaktifasi atau merusak organisme yang menyerang, menghilangkan zat iritan dan mengatur derajat perbaikan jaringan (Mycek, 2001). Hampir setiap orang Indonesia dan India serta bangsa Asia umumnya pernah mengkomsumsi tanaman rempah ini, baik sebagai pelengkap bumbu masakan, jamu, atau obat untuk menjaga kesehatan dan kecantikan. Kunyit sering digunakan dalam masakan sejenis gulai dan juga digunakan sebagai pewarna alamiah masakan / makanan agar berwarna kuning (Agoes, 2010).

Kunyit adalah tanaman rimpang yang sudah banyak dikenal oleh dunia, baik dalam skala rumah tangga maupun skala industri ( Paramitasari, dyah, 2011). Curcumin yang terkandung dalam rimpang kunyit bermanfaat sebagai antitumor dan anti-inflamasi (antiradang). Saponin berkhasiat sebagai antineoplastik (antikanker). Beta karoten, polifenol, dan flavonoid berfungsi sebagai antioksidan (Mangan, 2009).

\section{METODE PENELITIAN}

\section{Bahan}

Rimpang kunyit, etanol 96\% (PA), asam klorida 2 N, air suling, pereaksi mayer, pereaksi bouchardat, pereaksi dragendrof, serbuk magnesium, asam klorida pekat, amil alkohol, pereaksi besi (III) klorida $1 \%$, timbal (II) asetat 0,4 M, isopropanol, klorofrom, metanol, pereaksi molish, asam sulfat pekat, asam sulfat $2 \mathrm{~N}$, natrium hidroksida $2 \mathrm{~N}$, pereaksi lieberman-burchard, kloralhidrat, karagenan, indometasin, Karboksil Metil Celulosa (CMC) dan indometasin. 


\section{Skrining fitokimia}

Rimpang kunyit diambil di desa Ie-Imerah kecamatan Pasie Raja, Kabupaten Aceh Selatan kemudian diidentifikasi oleh Laboratorium Herbarium Medanese (MEDA) Universitas Sumatra Utara kemudian dilakukan skrining fitokimia pada serbuk rimpang kunyit yang meliputi alkaloid, flavonoid, glikosida, antrakinon, saponin, tannin dan steroid/triterpenoid dan minyak Atsiri.

\section{Pengujian Anti inflamasi}

Sebelum dilakukan percobaan, tikus dipuasakan tetapi tetap di beri minum selama 18 jam. Hewan dibagi dalam lima kelompok, yaitu kelompok kontrol (suspensi CMC 0,5\%), kelompok bahan uji (suspensi ekstrak etanol rimpang kunyit dengan dosis 400, 500, dan 600 $\mathrm{mg} / \mathrm{kg} \mathrm{bb}$ ), dan kelompok pembanding (suspensi indometasin dengan dosis $100 \mathrm{mg} / \mathrm{kg} \mathrm{bb}$ ).

Pada sendi kaki kiri diberi tanda sebagai batas pengukuran volume kaki tikus dan diukur volumenya sebagai volume awal (Vo), kemudian pada masing-masing telapak kaki tikus disuntik secara intraplantar dengan larutan indikator karagenan 1\% dengan volume $0,04 \mathrm{ml}$.

90 menit kemudian masing-masing tikus diberikan suspensi secara oral sesuai dengan kelompoknya. Setelah setengah jam, volume masing-masing kaki tikus diukur. Pengukuran dilakukan setiap selang waktu setengah jam selama 6 jam. Pengukuran dilakukan dengan cara mencelupkan kaki tikus kedalam alat plestimometer air raksa sampai batas tanda. Perubahan air raksa yang terjadi dicatat sebagai udema kaki tikus. Volume radang adalah selisih volume telapak kaki tikus setelah dan sebelum disuntikkan karagenan.

\section{Analisis Data}

Data hasil pengamatan efek antiinflamasi ekstrak rimpang kunyit terhadap radang pada telapak kaki tikus putih di analisis dengan Analisa Varian (ANAVA) dengan menggunakan program komputer SPSS. Untuk menguji adanya perbedaan yang bermakna antara kelompok uji (ketiga dosis ekstrak etanol rimpang kunyit) maupun kelompok pembanding (indometasin) terhadap kelompok kontrol (suspensi CMC) diuji dengan uji Duncan. 


\section{HASIL DAN PEMBAHASAN}

Tabel 1. Hasil Skrining Fitokimia terhadap Serbuk Kunyit

\begin{tabular}{cc}
\hline Pemeriksaan & Serbuk rimpang kunyit \\
\hline Alkaloid & + \\
Flavonoid & + \\
Saponin & - \\
Tanin & + \\
Antrakuinon & + \\
Steroida/triterpenoid & + \\
Minyak Atsiri & + \\
Glikosida & + \\
\hline
\end{tabular}

Data dianalisi dengan metode Anava (Analisa Varian) menggunakan program SPSS 19. Analisa dilakukan terhadap hasil perubahan volume kaki tikus dimulai dari 30 menit hingga 360 menit setelah penyuntikan bahan uji. Dari perubahan volume kaki tikus, dapat dihitung persen radang pada kaki tikus. Selanjutnya dibuat grafik perubahan persen radang rata-rata kaki tikus dan grafik perubahan persen inhibisi radang rata-rata kaki tikus.

Kelompok persen radang pada kaki tikus yang lebih kecil dari kelompok kontrol menunjukkan bahwa bahan bahan uji mampu menekan radang yang disebabkan oleh karagenan. Hasil pengukuran persen radang yang terjadi dapat dilihat pada Grafik 1 sebagai berikut :

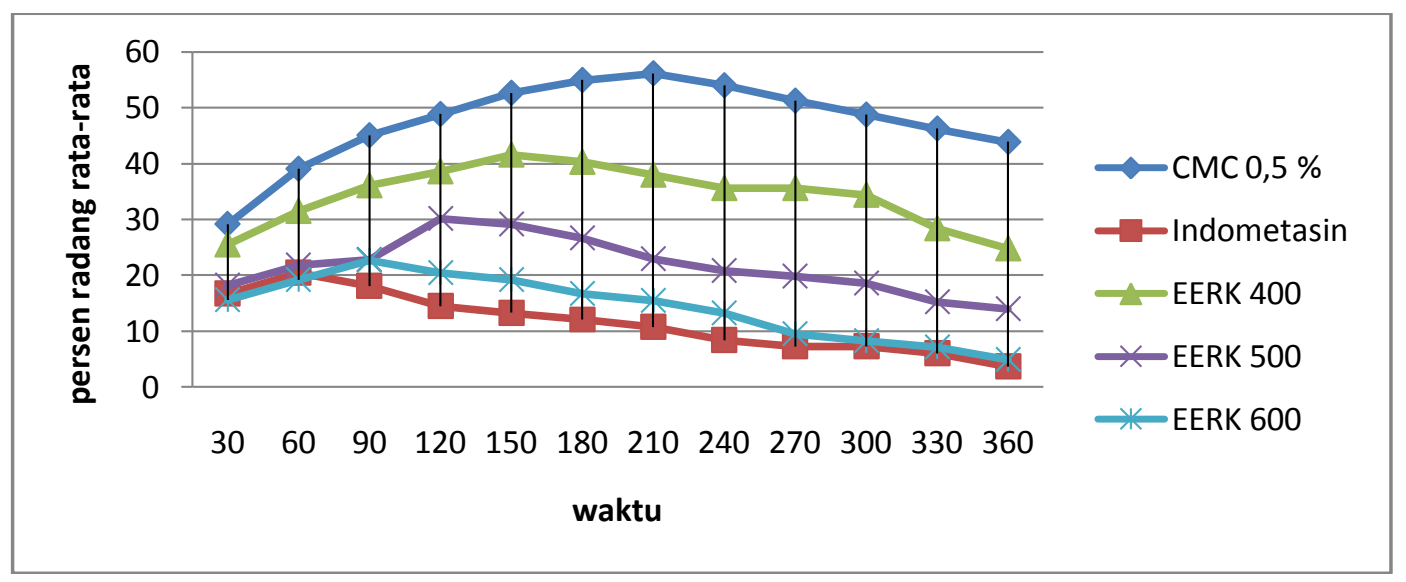

Grafik 1. Persen radang rata-rata telapak kaki tikus setelah pemberian oral suspensi ekstrak Etonol Rimpang Kunyit dosis $400 \mathrm{mg} / \mathrm{kg} \mathrm{BB}, 500 \mathrm{mg} / \mathrm{kg} \mathrm{BB}, 600 \mathrm{mg} / \mathrm{kg} \mathrm{BB}$, suspensi Indometasin $100 \mathrm{mg} / \mathrm{kg}$ BB dan suspensi CMC 0,5\% terhadap perubahan waktu. 
Pada grafik dilihat bahwa supensi indometasin $100 \mathrm{mg} / \mathrm{kg}$ BB memiliki persen radang yang lebih kecil dari pada EERK dosis 400, 500, $600 \mathrm{mg} / \mathrm{kg} \mathrm{BB}$, dan EERK dosis $600 \mathrm{mg} / \mathrm{kg}$ BB mempunyai persen radang yang lebih kecil dari pada EERK dosis 400 dan dosis 500 $\mathrm{mg} / \mathrm{kg} \mathrm{BB}$.

Efek antiinflamsi dapat dilihat dari besarnya persen hambatan radang rata-rata tiap waktu pengukuran yang dapat dilihat sebagai berikut:

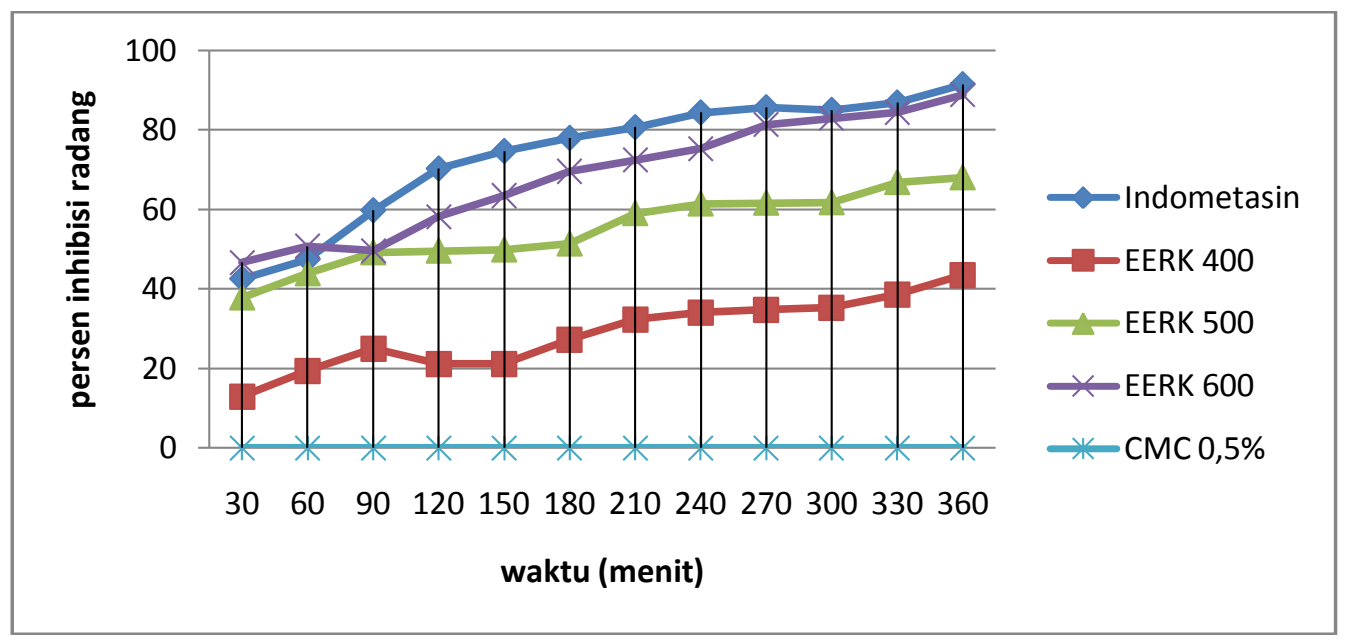

Grafik 2. Persen Inhibiasi Radang Telapak kaki Tikus Setelah Pemberian Oral Suspensi Ekstrak Etanol Rimpang Kunyit Dan Suspensi Indometasin

Pada grafik 2 dapat dilihat bahwa EERK $400 \mathrm{mg} / \mathrm{kg}$ BB memiliki persen hambatan radang yang lebih kecil dari pada EERK 500, $600 \mathrm{mg} / \mathrm{kg}$ BB dan dengan suspensi indometasin dosis $100 \mathrm{mg} / \mathrm{kg} \mathrm{BB}$, EERK $500 \mathrm{mg} / \mathrm{kg}$ BB memiliki persen hambatan radang yang lebih kecil dari EERK $600 \mathrm{mg} / \mathrm{kg}$ BB dan dengan suspensi indometasin dosis $100 \mathrm{mg} / \mathrm{kg}$ $\mathrm{BB}$, dan EERK dosis $600 \mathrm{mg} / \mathrm{kg}$ BB memiliki persen hambatan radang yang lebih kecil dari supensi indometasin $100 \mathrm{mg} / \mathrm{kgBB}$.

Analisa varians terhadap perubahan volume radang digunakan untuk melihat ada tidaknya perbedaan pengaruh obat uji yakni suspensi ekstrak rimpang kunyit terhadap suspensi CMC 0,5\% sebagai pembanding negatif dan suspensi indometasin sebagai pembanding positif.

Untuk melihat kelompok perlakuan mana yang memiliki efek yang sama atau berbeda dan efek yang terkecil sampai dengan yang terbesar antara yang satu dengan yang lain sehingga diperoleh susunan kelompok yang berbeda dilakukan dengan metode duncan, uji 
beda rata-rata > 0,05 menunjukkan bahwa antar perlakukan tidak ada perbedaan yang bermakna dan sebaliknya bila uji beda rata-rata $<0,05$ menunjukkan terdapat perbedaan yang bermakna untuk semua perlakuan dari menit ke-30 sampai menit ke-360.

Dalam pengujian dengan memakai darah utuh manusia, aspirin, indometasin, piroxicam dan sulindac lebih efektif dalam menghambat COX-1; ibuprofen dan meclofenamate menghambat kedua isozim (COX1-COX2) yang kurang lebih sama (Bolla dan Zoli, 2006: Claria and Romano, 2005). Benoxaprofen, AINS lain yang baru, diperlihatkan menghambat sintesis leukotriene dengan baik tetapi ditarik kembali karena sifat toksiknya (Castells, et al., 2006; Luciani, et al., 2007). Dari AINS yang sekarang ini bisa didapat, indomethacin dan diclofenac telah dilaporkan mengurangi sintesis prostagladin dan leukotriene (Katzung, 2002; Stolfi, et al., 2008).

\section{KESIMPULAN}

Hasil identifikasi tumbuhan menunjukkan bahwa bagian tumbuhan yang diteliti adalah rimpang kunyit (Curcuma domestica Val.). Skrining fitokimia serbuk dan ekstrak etanol rimpang kunyit mengandung alkaloid, Glikosida, Flavonoid, Antrakuinon, steroid/ terpenoid, tanin dan minyak atsiri. Pemberian suspensi ekstrak etanol rimpang kunyit dengan dosis 400, 500, dan $600 \mathrm{mg} / \mathrm{kg}$ BB dapat menurunkan radang pada kaki tikus yang diinduksi dengan karagenan $1 \%$.

Dari hasil pengujian statistik diperoleh bahwa pada pemberian secara oral suspensi ekstrak etanol rimpang kunyit dosis $600 \mathrm{mg} / \mathrm{kg}$ BB memiliki efek antiinflamasi yang lebih baik dibandingkan dengan suspensi ekstrak etanol rimpang kunyit dosis $400 \mathrm{mg} / \mathrm{kg}$ BB dan $500 \mathrm{mg} / \mathrm{kg}$ BB. Suspensi ekstrak etanol rimpang kunyit dosis $600 \mathrm{mg} / \mathrm{kg}$ BB menunjukkan efek antiinflamasi yang tidak berbeda secara nyata dengan suspensi indometasin dosis 100 $\mathrm{mg} / \mathrm{kg} \mathrm{BB}$.

\section{SARAN}

Disarankan kepada peneliti selanjutnya untuk menguji efek lain dari rimpang kunyit seperti uji antioksidan dan membuat fraksi-fraksi berdasarkan tingkat kepolaran pelarut dari masing-masing senyawa dapat dipisahkan dan ditentukan senyawa yang mana berkhasiat sebagai antiinflamasi. 


\section{DAFTAR PUSTAKA}

Agoes. (2010). Tanaman Obat Indonesia. Jakarta: Salemba Medika. Hal: 67.

Mangan, yelia. (2009). Solusi Sehat Mencegah dan Mengatasi Kanker. Jakarta: Agromedia Pustaka. Hal: 38.

Mycek. (2001). Farmakologi Ulasan Bergambar. Edisi 2. Jakarta: Widya medika. Hal: 404, $406,412$.

Paramitasari, dyah. (2011). Panduan, Praktis, Lengkap, dan Menguntungkan Budidaya Rimpang. Yogyakarta: Cahaya Atma. Hal: 31, 38.

Castells, A.; Paya, A.; Alenda, C.; Rodriguez-Moranta, F.; Agrelo, R.; Andreu, M.; Pinol, V.; Castellvi-Bel, S.; Jover, R.; Llor, X.; et al. (2006). Cyclooxygenase 2 expression in colorectal cancer with DNA mismatch repair deficiency. Clin. Cancer Res. (12). 1686-1692.

Luciani, M.G.; Campregher, C.; Gasche, C. (2007). Aspirin blocks proliferation in colon cells by inducing a g1 arrest and apoptosis through activation of the checkpoint kinase atm. Carcinogenesis (28). 2207-2217.

Claria J, Romano M. (2005). Pharmacological intervention of cyclooxygenase-2 and 5lipoxygenase pathways. Impact on inflammation and cancer. Curr Pharm Des. (11) 3431-3447.

Bolla M, Zoli W. (2006). Molecular characterization of cytotoxic and resistance mechanisms induced by NCX 4040, a novel NO-NSAID, in pancreatic cancer cell lines Apoptosis. (11) 1321-30. 